\title{
Dual Land Market and Rapid China’s Urbanization: Problems and Solutions
}

\author{
Huachun Wang ${ }^{1 *}$, Chunxue Zhao ${ }^{2}$, Maerhaba Xiaokaiti ${ }^{1}$, Yue Zhou ${ }^{1}$, Rui Zhao ${ }^{1}$ \\ ${ }^{1}$ Academy of Government, Beijing Normal University, Beijing, China \\ ${ }^{2}$ Research Institute for Fiscal Science, Ministry of Finance, Beijing, China \\ Email: "huachunwang@bnu.edu.cn
}

Received March 15 ${ }^{\text {th }}$, 2012; revised April 29 ${ }^{\text {th }}$, 2012; accepted May 15 $5^{\text {th }}, 2012$

\begin{abstract}
The dual land market has greatly encouraged the economy and urban development and created far-reaching effects on excessive land expropriation and land finance. Using an analytical framework of dual market structure model, this paper investigates the relationship between local land finance and China's rapid urbanization. Low-cost land expropriation is the main reason why extensive urbanization goes so fast in recent China. Granting farmers the complete land rights, implementing property tax to consolidate local tax bases, unifying the dual land market are helpful to achieve both social equity and land use efficiency in Chinese rapid urbanization process.
\end{abstract}

Keywords: Dual Land Market; Land Expropriation; Land Finance; Urbanization; China

\section{Introduction}

A new land development process was introduced in China upon the adoption of economic reforms since the early 1980's. Land use rights could be transferred as a transaction of ownership. China has been undergoing a rapid urbanization since then, the urbanization rate rose from 37.66 to 51.27 percent between 2001 and 2011 (NBS, 2012). Rapid urbanization has resulted in much arable land being used for non-agricultural purposes through land expropriation. Land distribution and its impact have been given less attention compared with the rapid gross domestic product (GDP) growth. Through the investigation of the formation of dual land market in the rapid urbanization, it can be observed that the formation of the dual land market is a complicated process involving conflicts of interests.

The legal frame work for land expropriation is defined by the Land Administration Law (LAL) enforced in 1998. The state may expropriate land for public interest. However, public interest has not been clearly defined. In fact, both the land for urban infrastructural and the land for commercial purpose are satisfied by land expropriation. Neither the rural collectives nor farmers can negotiate with the urban land users about the prices or other requirements (Qu, Heerink, \& Wang, 1995).

The compensation for arable land constitutes three components according to the LAL. The compensation for land is six to ten times the derived land productivity, which is the monetary value of the annual average agricultural output value over the past three years. The compensation for resettlement is four to six times the derived land productivity. The last item is the compensation for accessory assets in land. The maximum compensation for land expropriation cannot exceed 30 times the derived land productivity.

However, when the land is leased out for commercial purpose, the price will be much higher. The fair market value of the land and the negative impacts of land expropriations have

${ }^{*}$ Corresponding author. not been considered. The dispossessed farmers are largely excluded from sharing the land value appreciation resulting from land development projects (Wang \& Scott, 2008). There are currently over 40 million dispossessed farmers and 70 percent of them are related to rural land expropriation in urbanization (UIE, 2007a). Low compensation provoked dispossessed farmers into violent clashes with local authorities (Zhu \& Prosterman, 2007). Land-related issues have recently become the top cause of rural grievance, local social unrest and political instability (Carl, 2006; UIE, 2007b).

What is the relationship between land expropriation and urban expansion? Why the central government cannot curb local land expropriation? What further measures should be taken? This paper aims to address these questions. Based on an analytical framework of dual market structure theory, this paper focuses on the formation and operating framework of the dual land market, reveals its influence on the behaviours of local land finance and excessive land expropriation. The paper is organized as the following. After a brief introduction of the formation of dual land market in part two, part three describes the public land leasing strategies adopted by local governments in China. Part four rationalizes local land finance in a wider context of economic and political institutions in China. Part five examines the central government's response to local land expropriation. Policy implications are discussed regarding future reform of the land market.

\section{The Formation of the Dual Land Market and the Dynamics of Land Transactions}

As one of the pillars of Chinese public ownership, land is state-owned or collectively-owned, which emphasises that the government should monopolise the supply of land (Ho \& Spoor, 2006). Rural land can only be expropriated by the local government to ensure that all urban land belongs to the state. A dual land market emerged with the coexistence of market-ori- 
ented and non-market-oriented leased land under the public ownership and the monopoly land expropriation system. The dual land system differs not only in terms of the cost of obtaining land use rights but also in terms of property rights and the freedom of land transaction. To understand the dynamics of land transactions in China, it is important to understand the formation and dynamics of the dual land market (as Figure 1).

Dual land market works as the following. Local governments can lease the land through negotiation, tender or auction after land expropriation. As a typical administrative allocation method, negotiation between the land user and the government about leasing terms is the least transparent approach. Both tender and auction, which are market-oriented mechanisms, take place through public bidding. The highest bidder might be selected, but other factors, such as the land developers' reputation and the purpose the land is to be used might be taken into account.

As of Figure 1, local government plays an important role in the formation and dynamics of the dual land market. Stateowned units can apply for a land expropriation permit from the local government. They can then expropriate rural land by paying a standard compensation fee to the farmers. The local government can expropriate land directly from farmers and then allocate it to state units for public purposes. The government would also negotiate with the occupiers for public purpose and compensate them for their loss (Lin \& Ho 2005; Yao, 2002).

The use right of state-owned land can be exchanged in the market, but rural land can not. The local government monopolises land supply, it can expropriate rural land at a low price and sell it at a market price. Huge profits generate from the great difference between land expropriation compensation fees and land leasing prices (Tan, Xie, \& Lu, 2005).

Since the early 2000s, the revenue from residential and commercial land leased out by tender or auction has been increasing, while that of industrial land leased out by negotiation almost stable. Table 1 presents the national total area of leased land in 2007. As shown in Table 1, the proportion of land manufacturing accounted for 57.7 percent, while the residential and commercial land was the second and third. However, land revenue from the residential land is the highest while the revenue from the manufacturing purposes is the least. These figures show that land development activities have been rapidly growing as local governments have become increasingly involved in industrial development and urban expansion (Chai \& Wu, 2009).

Table 1 also presents the structure of land sites leased out by negotiation, auction or tender. The national total number of land sites leased out by negotiation accounts the large share, but the revenue of land sites leased out by auction or by tender share more. Leasing out industrial land at low prices implies that local governments are incurring net losses.

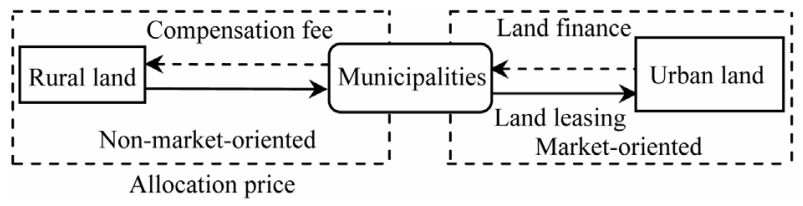

Figure 1.

The formation of dual land market in China.

Table 1.

Land leasing in 2007 in China.

\begin{tabular}{|c|c|c|c|c|c|c|c|c|}
\hline \multirow{2}{*}{ Land leasing types } & \multirow{2}{*}{ Land usage types } & \multicolumn{2}{|c|}{ Total land sites leased out } & \multicolumn{2}{|c|}{ Settled amount } & \multicolumn{2}{|c|}{ Net revenue } & \multirow{2}{*}{$\begin{array}{l}\text { Land leasing price } \\
\text { (Milloin/ha) }\end{array}$} \\
\hline & & $\mathrm{Mu}$ & Percentage & Million yuan & Percentage & Million yuan & Percentage & \\
\hline \multirow{5}{*}{ Total land leasing out } & Total & 3524408.9 & $100 \%$ & 1221672.1 & $100 \%$ & 454141.6 & $100 \%$ & 34.7 \\
\hline & Manufacture & 2034428.4 & $57.7 \%$ & 211020.3 & $17.3 \%$ & 6335.4 & $14.0 \%$ & 10.4 \\
\hline & Commercial & 404619.5 & $11.5 \%$ & 234950.5 & $19.2 \%$ & 83327.2 & $18.4 \%$ & 58.1 \\
\hline & Residential & 998628.3 & $28.3 \%$ & 753088.4 & $61.6 \%$ & 300116.5 & $66.1 \%$ & 75.4 \\
\hline & Others & 86732.7 & $2.5 \%$ & 22612.9 & $1.9 \%$ & 7340.5 & $1.5 \%$ & 26.1 \\
\hline \multirow{5}{*}{ Negotiation } & Total & 1764941.4 & $100 \%$ & 214186.2 & $100 \%$ & 75067.1 & $100 \%$ & 12.1 \\
\hline & Manufacture & 1505055 & $85.3 \%$ & 146975.2 & $68.6 \%$ & 45253.1 & $60.3 \%$ & 9.8 \\
\hline & Commercial & 73003.7 & $4.1 \%$ & 23469.6 & $11.0 \%$ & 11473.3 & $15.3 \%$ & 32.2 \\
\hline & Residential & 119098.4 & $6.8 \%$ & 29765.7 & $13.9 \%$ & 13854.5 & $18.4 \%$ & 25.0 \\
\hline & Others & 67784.4 & $3.8 \%$ & 13975.7 & $6.5 \%$ & 4486.3 & $6.0 \%$ & 20.6 \\
\hline \multirow{5}{*}{ Tender or auction } & Total & 1759467.3 & $100 \%$ & 1007485.9 & $100 \%$ & 379074.5 & $100 \%$ & 57.3 \\
\hline & Manufacture & 529373.3 & $30.1 \%$ & 64045.1 & $6.4 \%$ & 18104.3 & $4.8 \%$ & 12.1 \\
\hline & Commercial & 331615.7 & $18.8 \%$ & 211481.0 & $21.0 \%$ & 71853.9 & $19.0 \%$ & 63.8 \\
\hline & Residential & 879530.1 & $50.0 \%$ & 723322.7 & $71.7 \%$ & 286262.0 & $75.4 \%$ & 82.2 \\
\hline & Others & 18948.3 & $1.1 \%$ & 8637.2 & $0.9 \%$ & 2854.3 & $0.8 \%$ & 45.6 \\
\hline
\end{tabular}

Note: $\mathrm{Mu}$, a unit of area in China (Per Mu = 0.0667 hectares); Source: China statistical yearbook of land and resources (2008). 
Local government monopolies land supply in China. In order to extract more land revenue, many local governments set up Land Reserve Centers to limit land supply for commercial and residential purposes by auction or tender for a higher price. Local governments prefer maximize current-period land revenue by under-supplying residential and commercial land. Although land sites leased out by tender or auction is less, the revenue obtained constitutes a majority of local extra-budgetary revenue (Table 1). Between 2000 and 2010, the average leasing price of industrial land almost stable while the prices for commercial and residential land rose several times (NBS 2011).

Economic efficiency was not a factor in site determination under land leasing by negotiation. That was why low and flat land-use density buildings could be seen in the downtown area in China (as Table 2). Table 2 reveals a land-use pattern unlikely to be observed in western countries where industrial use accounted for only four to ten percent of built-up areas. The share of industrial use in China was more than twice as high as that in industrialized countries. Industrial land use accounted for 20 - 30 percent of the urban land in China. Residential land use accounted for less than 50 percent of all urbanized land. From three to five percent of industrial land in cities was vacant and 40 percent was used inefficiently (Yang \& Ralph, 2007).

The reason why local governments sacrifice the extra-budgetary revenue by negotiation with manufactures is mainly related with the current political system. According to the public finances reform implemented in 1994, all of the revenue from land leasing belongs to local governments' extra-budgets, so they should lease the land out by tender or auction for residential or commercial usage in order to generate more extra-budgetary revenue. Leasing land to manufacture sector may lead to a gain in local budgetary revenue through value-added tax, but the gain is limited after 75 percent of them turn over to the central government.

\section{Current Political System Drives Local Government Excessive Land Expropriation}

Under the current Chinese political system, local officials are mainly evaluated by economic indicators, which mainly include
GDP growth, employment, and the fiscal revenue. Therefore, local officials like to lease land for manufacturing purposes at low prices because the manufacturing sector can generate local GDP and employment. Then, they would have a potential chance for political promotion (Chan, 2003). Land revenue accounts for a large part of local fiscal income. Sales of land use rights increased from 231.3 billion yuan in 2001 to 1423.6 billion yuan in 2009 (Table 3). Major cities, such as Hangzhou and Shanghai, collected about 100 billion yuan recent years (NBS, 2010).

Excessive land expropriation partly contributed to social injustice and economic inefficiency. The industrial investment with low land incentive leads to serious waste of rural arable land, for example, there were 6015 industrial parks set up by various levels of local government across the country in 2006 (Zhai \& Xiang, 2007). A survey of 16 cities in 2005 showed that about 50 percent of the new land was under development (Xinhua News, 2006).

So far, most of the policies taken by the central government have not addressed the roots of land-related issues in the dual land market. For example, the state requires local governments to raise the compensation to maintain the farmers' living standards. However, the local governments have no incentive to do so. When the land leased at low prices, the central government require local governments to lease by auction or tender, but the local officials evade such regulations.

\section{Prospects of the Dual Land Market}

Market mechanisms need to be introduced into land expropriation. Land property rights to the farmers need to be established. Granting farmers to negotiate with land users about compensation fee would improve their welfare and contain the manufacturing investment by cheap land. It is crucial to distinguish public purpose from commercial purpose. The state should not be responsible for land expropriation for commercial purpose; instead, it should be decided by negotiation between the farmers and potential land users (Ding, 2003). All land for commerce, tourism, recreation, finance, services and commercial housing must be supplied by tender and auction. Government

Table 2.

Land use in major Chinese cities in the 1991. Unit: \%.

\begin{tabular}{cccccc}
\hline & Residential & Industrial & Infrastructure & Green space & Special uses \\
\hline Shanghai $^{\text {a }}$ & 49.6 & 30.5 & 7.3 & - & 12.6 \\
Beijing $^{\mathrm{a}}$ & 39.1 & 20.1 & 5.5 & - & 35.3 \\
Tianjin & 26.1 & 35.0 & 29.6 & 4.3 & 4.3 \\
Guangzhou $^{\mathrm{a}}$ & 35.9 & 37.0 & 17.1 & - & 9.9 \\
Shenyang & 29.6 & 28.0 & 23.8 & 6.9 & 11.8 \\
Chongqing & 34.0 & 33.4 & 27.0 & 3.1 & 5.4 \\
Wuhan & 26.8 & 30.4 & 25.0 & 7.0 & 8.8 \\
Zhenzhou & 25.5 & 28.3 & 37.8 & 7.9 & 0.6 \\
Xi'an & 44.5 & 29.3 & 25.9 & 26.6 & 0.1 \\
Harbin & 38.0 & 26.3 & 6.6 & 0.2 \\
\hline
\end{tabular}

Note: Infrastructure includes public services and transportation, etc. Source: Nanjing University of Geography and Lake Study, 1999. ${ }^{\text {a }}$ Shanghai, Beijing, and Guangzhou did not survey public services and infrastructure. 
Table 3.

The revenue from land leasing and its position in the local fiscal revenue.

\begin{tabular}{ccc}
\hline Year & $\begin{array}{c}\text { Local fiscal revenue } \\
\text { (billion) }\end{array}$ & $\begin{array}{c}\text { Land revenue/local fiscal } \\
\text { revenue (\%) }\end{array}$ \\
\hline 2001 & 780.3 & - \\
2002 & 851.5 & 34.8 \\
2003 & 980.5 & 37.8 \\
2004 & 1244.1 & 47.4 \\
2005 & 1509.2 & 36.5 \\
2006 & 1828.1 & 42.0 \\
2007 & 2356.5 & 50.9 \\
2008 & 2864.5 & 33.5 \\
2009 & 3285.1 & 48.8 \\
2010 & 3538.3 & 76.6 \\
\hline
\end{tabular}

Source: China statistical yearbook of land and resources (2002-2011).

should encourage fair land transaction within market channels (Zhu, 1999).

The collective should have a bundle of complete land property rights, and the farmers would be allowed to rent and transfer the rural land (Zhang, 2000). Land privatisation is helpful to unify the dual land market. Thus, local governments focus on regulating land use through effective urban and land use planning (Yi, 2009).

\section{Conclusion}

The root of land-related issues in urban expansion lies in the dual land market and low-cost land expropriation, unifying the dual land market and allowing farmers to negotiate with potential land users is an ideal choice. That would help dispossessed farmers to benefit from the land appreciation in urbanization process.

Local extra-budgetary revenue reduction would be offset by property tax. A property tax on existing residential and commercial real estate can be introduced to consolidate local tax bases. With the introduction of property taxes, the negative impacts of marketizing land expropriation on local fiscal revenue would be offset.

\section{Acknowledgements}

Thank the critical comments given Prof. Jianping Xie, Southwest University of Chongqing, and Dr. Xinchuan Wang, Economic Daily of China.

\section{REFERENCES}

National Bureau Statistics of China (NBS) (2012). China Statistical Yearbook of Land Resource. Beijing: China Statistical Press.
Qu, F. T., Heerink, N., \& Wang, W. M. (1995). Land administration reform in China: Its impact on land allocation and economic development. Land Use Policy, 3, 193-203. doi:10.1016/0264-8377(95)00003-V

Wang, Y., \& Scott, S. (2008). Illegal farmland conversion in China's urban periphery: Local regime and national transitions. Urban Geography, 4, 327-347. doi:10.2747/0272-3638.29.4.327

Unirule Institute of Economics (UIE) (2007a). Protection of land property rights in China's urbanization. Unirule Institute of Economics working paper. Beijing: Unirule Institute of Economics.

Zhu, K., \& Prosterman, R. (2007). Securing land rights for Chinese farmers: A leap forward for stability and growth. Development Policy Analysis, 4, 1-19.

Carl, M. (2006). Xinfang: An alternative to formal chinese legal institutions. Stanford Journal of International Law, 1, 103-179. doi:10.1017/S0305741008000039

Unirule Institute of Economics (UIE) (2007b). Protection of land property rights in China's urbanization. Beijing: Unirule Institute of Economics.

Ho, P., \& Spoor, M. (2006). Whose land? The political economy of cadastral development in transitional states. Land Use Policy, 4, 580 603. doi:10.1016/j.landusepol.2005.05.007

Lin, C. S., \& Ho, P. S. (2005). The state, land system, and land development processes in contemporary China. Annals of the Association of American Geographers, 2, 411-436. doi:10.1111/j.1467-8306.2005.00467.x

Yao, Y. (2002). Rural land system: An analysis framework. Journal of China Social Science, 1, 54-65.

Tan, M., Li, X., Xie H., \& Lu, C. (2005). Urban land expansion and arable land loss in China: A case study of Beijing-Tianjin-Hebei region. Land Use Policy, 3, 187-196. doi:10.1016/j.landusepol.2004.03.003

Chai, J. M., \& Wu, J. B. (2009). Rural construction land and rural land reform. Land and Resource, 11, 10-22.

National Bureau Statistics of China (NBS) (2011). China Statistical Yearbook of Land Resource. Beijing: China Statistical Press.

Yang, J. W., \& Ralph, G. (2007). Assessing the transportation consequences of land use transformation in urban China. Habitat International, 3-4, 345-353. doi.org/10.1016/j.habitatint.2007.05.001

Chan, N. (2003). Land expropriation compensation in China-problems \& answers. International Real Estate Review, 1, 136-152.

National Bureau Statistics of China (NBS) (2010). China Statistical Yearbook of Land Resource. Ministry of Land Resources of China. Beijing: China Statistical Press.

Zhai, N., \& Xiang, G. Q. (2007). An analysis of China's current land expropriation system and policy implications. China Administration, 6, 9-12.

Xinhua News (2006) Land supply tightened to curb economic overheating. URL (last checked September 2006).

http://english.cri.cn/2946/

Ding, C. R. (2003). Land policy reform in China: Assessment and prospects. Land Use Policy, 2, 109-120. doi:10.1016/S0264-8377(02)00073-X

Zhu, J. (1999). Local growth coalition: The context and implications of China's gradualist urban land reforms. International Journal of Urban and Regional Research, 3, 534-548. doi:10.1111/1468-2427.00211

Zhang, T. (2000). Land market forces and government's role in sprawl. Cities, 2, 123-135. doi:10.1016/S0264-2751(00)00007-X

Yi, X. R. (2009). The theoretical basis and effects of the "New Deal" on real estate. Jiangsu Social Science, 7, 39-46. 